\title{
THE EFFECT OF USING MNEMONIC TECHNIQUE TOWARD STUDENTS' VOCABULARY MASTERY AT GRADE XII-SCIENCE STUDENTS OF SMAN 9 KOTA BENGKULU
}

\author{
LIZA OKTARINI \\ BAMBANG SUWARNO \\ I WAYAN DHARMAYANA
}

UNIVERSITY OF BENGKULU

\begin{abstract}
This study aimed to find out whether the use of Mnemonic technique affected the students' vocabulary mastery. This study employed a quasi experimental design. The subject of this study comprised 64 students of grade XII science class of SMAN 9 Kota Bengkulu. The instrument of this study was a vocabulary test. The experiment class was taught by Mnemonic technique, while the control class by contextual learning. In the pre test there was no significant difference in mastery between the experiment class $($ mean $=71,18)$ and control class $($ mean $=68)$ with $t$ count $(0,1)<\mathrm{t}$ table $(\mathrm{df}=62$ sig 0,05$)$. After the use of Mnemonic technique, in the post test, there was a significant difference in mastery between the experiment class (mean=73,51) and control class (mean=67,53), with $\mathrm{t}_{\text {count }}$ $(1,99)>\mathrm{t}$ table $(1,67),(\mathrm{df}=62$; sig. 0,05$)$. It can be concuded that the use of Mnemonic technique was effective toward the students' vocabulary mastery at grade XII-Science Students of SMAN 9 Kota Bengkulu.
\end{abstract}

Key Words: Vocabulary Mastery, Mnemonic Technique

\section{PENGARUH PENGGUNAAN TEKNIK MNEMONIC TERHADAP PENGUASAAN KOSA KATA SISWA PADA KELAS XII IPA SMAN 9 KOTA BENGKULU}

\begin{abstract}
ABSTRAK
Penelitian ini bertujuan untuk menemukan apakah penggunaan Mnemonic teknik berpengaruh terhadap penguasaan kosakata siswa. Penelitian ini menggunakan desain eksperimen. Subjek penelitian ini yaitu 64 siswa kelasXII-IPA SMAN 9 Kota Bengkulu. Instrumen penelitian ini yaitu tes penguasaan kosa kata. Kelas ekserimen diajar menggunakan Mnemonic teknik, sedangkan kelas kontrol dengan pembelajankontekstual. Dalam pre-test tidak terdapat perbedaan yang signifikan dalam penguasaan antara eksperimen kelas (rata-rata=71,18) dan kontrol kelas (rata-rata=68) with $t_{\text {count }}(0,1)<t_{\text {table }}$ $(\mathrm{df}=62 \mathrm{sig} 0,05)$. Setelah penggunaan Mnemonic teknik, dalam post-test, terdapat sebuah perbedaan yang signifikan dalam penguasaan antara eksperimen kelas $($ mean $=73,51)$ dan kontrol kelas (mean=67,53), with $t_{\text {count }}(1,99)>t_{\text {table }}(1,67),(d f=62$ sig 0,05). Itu dapat disimpulkan bahwa penggunaan Mnemonic teknik efektif terhadap penguasaan kosa kata pada siswa kelas XII-IPA SMAN 9 Kota Bengkulu.
\end{abstract}

Kata Kunci: Penguasaan Kosakata, Teknik Mnemonic INTRODUCTION 
Vocabulary is the most important thing in learning language, because it is the basic knowledge of someone to master all language skill. If we want to learn a new language we needs to deep about vocabulary so that can speak fluently. Thus, It be one of the keys to becoming a fluent reader. The students who have many vocabularies will be easier to understand a text that is read. Vocabulary can help the students easily in practice and use language. Saricoban and Balaman (2008:2) stated that, the important of learning vocabulary in foreign language teaching cannot be neglected at present. Although less importance was given to vocabulary learning in the past, many experienced teacher of English have realized that knowing a language means knowing its vocabulary as well. Manurung (2003) stated that the ability of speaking, listening, reading and writing English depends on the mastery of vocabulary and grammar. For English lesson, the objective of English lesson is to give knowledge of vocabulary mastery so that when the students continue their education to a higher level, they will not get any difficulties (Listia and Kamal: 2008).

\begin{tabular}{llr}
\multicolumn{2}{c}{ Furthermore } & English \\
vocabulary & mastery & is \\
comprehensive & knowledge
\end{tabular} recognize, understand, and produce stock of words and their meaning. According to Adger (2002) vocabulary is not only confined to the meaning of words but also includes how vocabulary in a language is structured: how people use and store words and how they learn words and the relationship between words, phrases, categories of words and phrases. Moreover, vocabulary mastery also in line with another English skills, such as: listening, reading, writing, and speaking. It means that if a student has a lot of vocabulary, the student will get the ease in learning those four skills.

$$
\text { Based on previous }
$$

observation and interview done at grade XII-Science students of SMAN 09 Kota Bengkulu, the researcher found some problems on students' ability in English. The students have difficulty in spelling and arranging the sentence. Then the students are less of vocabulary mastery. Another problem is students' more anxiety and afraid in practice English speaking. And the last, the teacher only give monotone technique and media in teaching and learning process, so that the students felt boring in their class. Moreover, students' speaking score is still low. It was proved by the baseline data of students' score which was only 50\% or 16 students got passing grade. Due to, the problem above a new and innovative method must be applied to solve the problems.

The researcher used Mnemonic as a new strategy for solving the problems mentioned above. Mnemonic is devices are used for remembering information that needs to be memorized, but not necessarily understood. A general rule for any type of mnemonic device is that it must be simple, clear and vivid. Moreover, Baddley (1989) said that A mnemonic is a memory aid, a way of helping to ensure we retain information which would otherwise be forgotten. Most mnemonics involve first reducing the amount of information to a minimum then elaborating this minimal 
information in a more memorable way. There are several kinds of Mnemonic, they are; acronym, acrostics, loci, keyword, reconstructive, and double keyword.

Since Mnemonic is a technique which rarely applied in High School level in Kota Bengkulu, therefore the researcher needs to do a study to find out the data whether Mnemonic technique is effective or not in teaching vocabulary. According Wolgemuth at al (2007), the keyword, pegword, and reconstructive elaboration mnemonic strategies have proven effective across many studies and have shown effective for middle school and high school age students. From some kinds of mnemonic strategies the researcher will use keyword method. The Mnemonic Technique or Keyword Method was introduced to vocabulary teaching by Atkinson (1975) who proposed the keyword method as a supplementary technique for foreign language vocabulary study and reported that it is superior to rote rehearsal technique for vocabulary and strongly claims that this method is highly useful for both foreign and native language learning. Thus, the researcher will use keyword method as mnemonic tool to teach vocabulary. In this study, the kinds of vocabulary taught were noun, adjective, and verb, among the students in narrative text design. The study question was: 1 . Did the use of Mnemonic technique affect students' vocabulary mastery?

\section{METHODOLOGY}

This study used a quasiexperimental design to investigate whether the use of mnemonic technique can help students' improve their voabulary mastery. According to Hatch and Farhady (1982), a quasi experimental design is a practical agreement between true experimental and the nature of human language behaviour. There were two classes employed as the sample of the study. Class XII Science 1 consisting of 32 students as experimental group that received Mnemonic technique as a treatment. The second class was XII Science 2 consisting of 32 students took part as the control group of the study. The instrument of this study was students' vocabulary test.

In conducting a teaching program in experimental and control groups, the researcher acted as a teacher who uses mnemonic technique in experimental group and common strategy in control group during teaching-learning process. The teaching vocabulary for the experimental and control groups were carried out in the same procedure by using pre-activities, whilst-activities and post-activities. After collecting data, the result from the instrument (pre-test and post-test) was analyzed in order to answer the study question. Normality, homogeneity, and independent sample t-test was run.

\section{FINDINGS AND DISCUSSION}

\section{a. Data Analysis on Pre-Test}

1) Normality Test Result

After trying out the instrument, the researcher did the researcher and gave the pre-test to the students. However, the normality of the students pre test result must be known to decide whether the sample was normal or not. Furthermore, the normality test was examined using SPSS. 
Table 1

Normality of the pre-test using SPSS

\begin{tabular}{|l|r|r|r|r|r|r|}
\hline \multirow{2}{*}{ rogorov-Smirnov $^{\mathrm{a}}$} & \multicolumn{4}{|l|}{ Shapiro-Wilk } \\
\cline { 2 - 7 } & & & & & & \\
\hline & .079 & 64 & .200 & .964 & 64 & .062 \\
\hline
\end{tabular}

According to table 1, the results of experiment and control group were not statistically significant at the 0.05 level $(\mathrm{df}=64, \mathrm{p}$ $>0.05$ ). It means the data of the sample came from normally distributed population. As the normality in the pre-test was normal, an independent sample t-test can be used to analyze the data.

2) Homogeneity Test Result

Homogeneity test result was run to know whether the data of pretest result homogenous or not. F test

formula was used to test the homogeneity pre- both experiment and control group. The Levene's Test for equality of vaiances shows $\mathrm{p}=$ $0.611>0.05$, proving that the variances both groups was equivalent. Thus, the samples assigned to the experiment and control group were not initially different but homogeneus.

b. Data Analysis on Post Test

1) Normality Test Result

The table 2 below will show the normality test result on post test using SPSS.

Table 2

Normality of the pre-test using SPSS

\begin{tabular}{|c|c|c|c|c|c|c|}
\hline & hogorov-Sr & & & Shapiro-W & & \\
\hline & .019 & 64 & .058 & .955 & 64 & .021 \\
\hline
\end{tabular}

According to table 4.6, the results of experiment and control group were not statistically significant at the 0.05 level $(\mathrm{df}=64, \mathrm{p}$ $>0.05$ ). It means the data of the sample came from normally distributed population.

2) Homogeneity Test Result

F test was used to test the homogeneity post-test result both experiment and control group. The Levene's Test for equality of vaiances shows $\mathrm{p}=0.630>0.05$, proving that the variances both groups was equivalent. Thus, the samples assigned to the experiment and control group were not initially different but homogeneus.

\section{Examining the Hypotheses}

Since the pre- test result both experiment and control group distributed normal and the sample was homogenous, the independent sample t-test was run. The independent sample t-test was used 
to examine the hypotheses proposed, they were:

1. The hypothesis that relate to sub problem 1.a

$\mathrm{H}_{1}=$ There is significant difference in mastery between the experiment class and control class before the experiment (at the pre-test)
$\mathrm{H}_{0}=$ There is no significant difference in mastery between the experiment class and control class before the experiment (at the pretest)

Before the experiment, both groups had similar ability. The independent sample t-test using SPSS also revealed similar result.

Table 3

A comparison of pre-test scores between experiment and control group

\begin{tabular}{lcccc}
\hline \multicolumn{1}{c}{ Group } & $\overline{\boldsymbol{X}}$ & Df & T & Sig. (2-tailed) \\
\hline Experiment $(\mathrm{n}=24)$ & 71,25 & 62 & 1.180 & .243 \\
Control $(\mathrm{n}=24)$ & 67,87 & & & \\
Mean Difference & 3,38 & & & \\
\hline
\end{tabular}

The result showed $\mathrm{t}=1.180$, $\mathrm{df}=62$, and $\mathrm{p}=0.243>0.05$, indicating that the two groups did not differ significantly, but were homogeneous with mean difference was about 3.38. Therefore, it can be concluded that both groups were homogenous at the outset of the study.

Moreover, the independent sample t-test was used to examine the hypotheses proposed on post test, they were:
The hypothesis that relate to sub problem 1.b

$\mathrm{H}_{1}=$ There is significant difference in mastery between the experiment class and control class after the experiment (at the post-test)

$\mathrm{H}_{0}=$ There is no significant difference in mastery between the experiment class and control class after the experiment (at the post-test) The independent sample t-test using SPSS also revealed similar result.

Table 4

A comparison of pre-test scores between experiment and control group

\begin{tabular}{lcccc}
\hline \multicolumn{1}{c}{ Group } & $\overline{\boldsymbol{X}}$ & Df & T & Sig. (2-tailed) \\
\hline Experiment (n=24) & 73,31 & 62 & 2.156 & .035 \\
Control (n=24) & 67,53 & & & \\
Mean Difference & 5,78 & & & \\
\hline
\end{tabular}

Furthermore, the result showed $\mathrm{t}=2.156, \mathrm{df}=62$, and $\mathrm{p}=$ 0.035 , indicating that the two groups differ significantly. So the null hypotheses stating that no significant difference existed in the scores of the students who were controlled to receive Mnemonic technique was rejected.
There was no difference in vocabulary mastery between the experiment class and control class before the use of Mnemonic technique at grade twelfth SMAN 9 Kota Bengkulu. However, there was significant difference in mastery between the experiment class and control class after the use of 
Mnemonic technique at grade twelfth SMAN 9 Kota Bengkulu. In other words, the use of Mnemonic technique was efective toward improving students' vocabulary mastery at grade twelfth SMAN 9 Kota Bengkulu.

Mnemonic instruction is a way to help students remember information/vocabulary more effectively and easily. It involves linking unfamiliar to be learned information with familiar already known information through the use of a visual picture or letter/word combinations. The use of mnemonics instruction with young adults at the secondary level had been of particular interest as secondaryschool students, specifically those with disabilities, are particularly at risk in academic settings. (Wolgemuth, Cobb, \& Alwell, 2008). "Mnemonics are effective when they speed up learning, reduce confusion among similar items, and enhance long-term retention and application of the information." (Shmidman, \& Ehri, 2010, pg. 160).

Furthermore, this research result also confirmed the theory from Wolgemuth at al (2008) who states that the keyword, pegword, and reconstructive elaboration mnemonic strategies have proven effective across msignificant studies and have shown effective for middle school and high school age students with learning disabilities. Moreover, Atkinson and Raugh (1975) stated that Mnemonic devices have been used for msignificant centuries. These have proven effective in improving both immediate and delayed recall of L2 or FL vocabulary.

The focus of mnemonic strategies is so specific that they are intended to be implemented to enhance the recall of the components of significant lesson for which memory is needed. These strategies are also not comprehension strategies, but strategies to aid the recall of new information. It should be noted that students who are trained mnemonically also perform better on comprehension tests of that specific content (e.g., Mastropieri, Scruggs, \& Fulk, 1990; Scruggs, Mastropieri, McLoone, Levin, \& Morrison, 1987), but that is generally because the implementation of the mnemonic strategies helps them remember more information that can be applied on comprehension tests.

The keyword method is a mnemonic (memory-enhancing) technique used to increase the initial learning and retention of facts and fact systems which young adults often encounter in schools. This method incorporates both auditory and visual cues to enhance meaningfulness of the information to be learned and to promote strong associations between questions and answers (Mastropieri, 1988). The keyword, pegword, and reconstructive elaboration mnemonic strategies have proven effective across msignificant studies and have shown effective for middle school and high school age students with learning disabilities (Wolgemuth, Cobb, \& Alwell,, 2008). In addition, "mnemonic devices, such as acrostics, acronyms, narratives, and rhymes, can assist in making abstract material and concepts more meaningful for individuals" (Laing, 2010, 349).

The result of this study was also similar to the result of some previous studies. Firstly, Saricoban 
\& Basibek (2012) proved that mnemonics technique is more effective than the context method in immediate and delayed recall and recognition of the vocabulary. This study result was in line with this present study which proved that Mnemonic was effective to recall the students' vocabulary while learning. It also proved that the students' score in experiment group was more than control group.

Second, the study result from. Bakkenn (2014) who defined that the manuscript will present a variety of mnemonic strategies that can be very useful when working with young adult learners in improving their vocabulary knowledge. Similar to this study, the students' score in experiment group at pre-test improved at post-test. It means that the mnemonic strategies worked well among adult learners in improving their vocabulary knowledge.

It also confirms the study result from Benge \& Robbin (2011) which found that the keyword mnemonic method was effective with

\section{CONCLUSION}

To conclude, this mnemonic technique is effective to be applied for teaching vocabulary. It is not only can be applied in Science class, but also in Social class at senior high school level. Furthermore, the small class taken as the sample and kinds of vocabulary used in this study becomes the limitation of this study. the Students. The keyword method is a mnemonic (memory-enhancing) technique used to increase the initial learning and retention of facts and fact systems which young adults often encounter in schools. This method incorporates both auditory and visual cues to enhance meaningfulness of the information to be learned and to promote strong associations between questions and answers (Mastropieri, 1988).

Thus, Mnemonic strategies have been proven to help individuals remember information by making it easier to remember and more concrete. These strategies work with all kinds of students and it can be applied to significant type of content. Although mnemonic strategies can be very beneficial, it is important to choose the incorrect method or it will not benefit the learner. Although every mnemonic strategy was not presented, this information should provide a starting point for assisting young adult learners in improving their vocabulary knowledge.

The researcher also suggested for English teachers to classify the group of vocabulary that will be used. It must be appropriate to the level of students. Thus, Further study studies can be conducted to compare the effects of using mnemonic techniques on students' vocabulary mastery.

\section{REFERENCES}


Atkinson, R.C. \& Raugh, M.R. (1975) An application of the mnemonic keyword method to the acquisition of a Russian vocabulary. Journal of Experimental PsycholoRy: Human Learning and Memory, 1, 126-133.

Atkinson,

R.C.

Mnemotechniques in secondlanguage learning. American Psychologist, 30, 821-828.

Baddley (1989). Mnemonic methods in foreign language vocabulary learning: Theoretical considerations and pedagogical implications. In J. Coady, \& T. Huckin (Eds.) Cambridge: Cambridge University Press.

Bakken (2011), Chapter 4 History of learning disabilities, in Anthony F. Rotatori, Festus E. Obiakor, Jeffrey P. Bakken (ed.) History of Special Education (Advances in Special Education, Volume

21) Emerald Group Publishing Limited, pp.61 - 87

Benge and Robbin (2009). Mnemonic methods in foreign language vocabulary learning: Theoretical considerations and pedagogical implications. Published journal

Harmer, Jeremy. (2007). The practice of English language Teaching (Longman Handsbooks for Language Teacher). New York: Longman Inc.

Hatch and Farhady. 1982. Quai experimenal study review. New York: Oxford University Press

Higbee, K. L. (1987). Process mnemonics: Principles, prospects, and problems. In M. A. McDaniel \& M.
Pressley (Eds.), Imagery and Related Mnemonic

Processes: Theories,

Individual Differences, and Applications (pp. 407-427). New York: Springer-Verlag

Hunt, N. (2010). Using mnemonics in teaching statistics. Teaching Statistics, 32(3), 73-75.

Husltijn, H. J. (1997). Mnemonic methods in foreign language vocabulary learning: Theoretical considerations and pedagogical implications. In J. Coady, \& T. Huckin (Eds.), Second language vocabulary acquisition (p. 203-224). Cambridge: Cambridge University Press.

Judy K.(2007). Montgomery's book: The Bridge of Vocabulary: Evidence Based Activities for Academic Success.

Khalafi \& Oroji. (2016).Mnemonics technique versus context method in teaching vocabulary at upperintermediate level. Education and Science,37, 251-266.

Listia,N and Kamal, L. (2008). The teaching of learning strategies. Improving The Students' Vocaulary Mastery in Writing Narrative Text Through Picture Series at The Tenth Grade of SMA PGRI 1 Tuban. Published Thesis University of PGRI RonggowaleTuban.

Shmidman, A., \& Ehri, L. (2010). Embedded picture mnemonics to learn letters. Scientific Studies of Reading, 14(2), 159182.

Solso, R. L. (1995). Cognitive psychology (4th Ed.). Boston: Allyn and Bacon. 
Sugiyono. (2009). Metode Penelitian Bisnis (Pendekatan Kuantitatif, Kualitatif, dan R\&D). Bandung: Alfabeta.

Thornburry, Scott. (2002). How to teach vocabulary. Longman: Malaysia.

Ur, Penni. (1996). A Course in language teaching. Cambridge : Cambridge University Press.

Wilkins. (1982). Vocabulary in language teaching. Cambridge: Cambridge University Press.
Wolgemuth at al (2007). Mnemonic methods in foreign language vocabulary learning: Theoretical considerations and pedagogical implications. Published journal

Venderber. (2012).The teaching of learning strategies.In M. C. Wittrock (Ed.), Handbook of study on teaching (pp. 315327). New York: Macmillan.

Yates, F. A. (1966). The art of memory. London: Routledge \& Kegan Paul. 